\title{
Negative Pressure Wound Therapy Using Polyurethane Foam in a Patient with Necrotizing Fasciitis
}

\author{
ADELAIDA AVINO ${ }^{1}$, CRISTIAN RADU J ECAN ${ }^{1,2}$, CRISTINA NICOLETA COZMA ${ }^{1,2}$, ANDRA ELENA BALCANGIU STROESCU ${ }^{3,4 *}$, \\ DANIELA GABRIELA BALAN ${ }^{3}$, DORIN IONESCU ${ }^{5,6}$, ANDRADA MIHAl ${ }^{7,8}$, MIHAELA TANASE ${ }^{9}$, LAURA RADUCU ${ }^{1,2}$ \\ 1Prof.Dr.Agrippa Ionescu Clinical Emergency Hospital, Department of Plastic and Reconstructive Surgery, 7 Ion Mincu Str., \\ 011356, Bucharest, Romania \\ ${ }^{2}$ Carol Davila University of Medicine and Pharmacy, Faculty of Medicine, Discipline of Plastic and Reconstructive Surgery, 37 \\ Dionisie Lupu Str., 020021, Bucharest, Romania \\ ${ }^{3}$ Carol Davila University of Medicine and Pharmacy, Faculty of Dental Medicine, Discipline of Physiology, 37 Dionisie Lupu Str., \\ 020021, Bucharest, Romania \\ ${ }^{4}$ Emergency University Hospital Bucharest, Department of Dialysis, 169 Splaiul Independentei, 050098, Bucharest, Romania \\ ${ }^{5}$ Carol Davila University of Medicine and Pharmacy, Faculty of Medicine, Department of Medical Semiology, Discipline of Internal \\ Medicine I and Nephrology, 37 Dionisie Lupu Str., 020021, Bucharest, Romania \\ ${ }^{6}$ Emergency University Hospital Bucharest, 169 Splaiul Independentei, 050098, Bucharest, Romania \\ 'University of Medicine and Pharmacy Carol Davila Bucharest, Faculty of Medicine,Discipline of Diabetes, Nutrition and Metabolic \\ Diseases N. Paulescu National Institute, 5-7 Ion Movila Str., 030167, Bucharest, Romania \\ ${ }^{8}$ Nutrition and Metabolic Diseases Prof. N. Paulescu, Department II of Diabetes, Nutrition and Metabolic Diseases National \\ Institute of Diabetes, 5-7 Ion Movila Str., 030167, Bucharest, Romania \\ ${ }^{9}$ Carol Davila University of Medicine and Pharmacy, Faculty of Dental Medicine,Department of Pedodontics, 37 Dionisie Lupu \\ Str., 020021, Bucharest, Romania
}

\begin{abstract}
Negative pressure wound therapy is one of the newest methods of treatment used in wound healing. An important role of the system has a foam dressing that connects the wound with the vacuum. In general the sponge used in vacuum assisted therapies is made of polyurethane foam. We present the case of a 51-yearold male patient with a history of deep vein thrombosis (known for about 3 years) diagnosed with necrotizing fasciitis (NF). In this patient, after each step of the surgical treatment (large debridement and skin grafting) negative pressure wound therapy using polyurethane foam was used.
\end{abstract}

Keywords: necrotinzing fasciitis, negative pressure, polyurethane foam, skin grafting

Necrotizing fasciitis (NF) is a devastating, potentially life-threatening disease of the skin and soft tissue that produces rapidly extensive tissue necrosis[1]. It affects the extremities, the abdominal wall, but also the perineal area[2]. The main cause is the inoculation of the microorganisms into the subcutaneous layer of the skin. Trauma is considered to be the main reason in patients with history of lesions of the epithelial or mucosal surface[3]. The mortality rate is high [2], up to $36 \%$ [4], taking in the consideration the fact that the patients can develop septic shock. It is correlated with numerous comorbidities such as diabetes mellitus, immunosuppression, peripheral vascular disease, chronic renal failure and liver cirrhosis [2].

Is is considered to be a flesh-eating disease, which was first named necrotizing fasciitis in the 1950s by BL Wilson. He was describing the rapid destruction of tissue with necrosis of the fascia and subcutaneous tissue [5]. NF affects from 4 to 10 persons in 1000.000 per year [4]. The most common bacterias implicated are group $A \beta$ hemolytic Streptococcus and Clostridium perfringens [6].

Early diagnosis is difficult to be settled, but it is mandatory to be done due to the fact that any delay of the proper treatment could increase the rate of amputation and could cause systemic inflammatory response syndrome leading to a higher mortality rate [2].

\section{Experimemntal part}

A 51-year-old male patient presented to the Department of Plastic Surgery of Prof. Dr. Agrippa Ionescu Emergency Clinical Hospital with aggressive pain and erythema of the right lower leg. The patient was a nonsmoker, with arterial hypertension and a history of deep vein thrombosis and he declared to have a minor trauma of the right lower leg.

At that time lab results revealed serum creatinine of 3.7 $\mathrm{mg} / \mathrm{dl}$, urea $90 \mathrm{mg} / \mathrm{dL}$, serum hemoglobin $(\mathrm{Hb}) 12.3 \mathrm{~g} / \mathrm{dL}$, $\mathrm{Na} 133 \mathrm{mmol} / \mathrm{L}, \mathrm{Fe} 9 \mu \mathrm{g} / \mathrm{dL}$, and white blood cells $3200 /$ $\mu \mathrm{L}$. Upon admission, the patient also had a significant inflammatory syndrome - fibrinogen $701 \mathrm{mg} / \mathrm{dL}, C$-reactive protein $339.71 \mathrm{mg} / \mathrm{L}$, procalcitonin $8.09 \mathrm{ng} / \mathrm{mL}$. Due to the fact that he presented acure kidney injury with anuria the patient was sent directly to the intensive care unit and supportive therapies were initiated. After $12 \mathrm{~h}$ he had NTproBNP $1785 \mathrm{pg} / \mathrm{mL}$ and mioglobin $190 \mu \mathrm{g} / \mathrm{L}$.

After 2 days in the intensive care unit, large blisters and hemorrhagic bullae appeared all over the lower right leg. Wound cultures were performed and empirical antibiotherapy was started.. Because the general status of the patient was deteriorating emergency surgical debridement was decided. Skin incisions were performed in the longitudinal direction along the muscle-fascial layers. A hematoma was evacuated from the posterior compartment lower leg. An antiseptic dressing was applied all over the thigh. The antiseptic dressing was changed every day in aseptic conditions. Antibiotics were adjusted according to the positive results of wound swab cultures, our patient having Escherichia coli.

On day 7 of admission, the patient presented skin necrosis with purulent bullae and crepitus all over the lower right leg. He underwent further surgical exploration. An aggressive debridement was performed revealing extensive necrosis of fascia and subcutaneous tissue (fig. 1). Excision of the infected and necrotic tissue was realised until healthy tissue was revealed. 


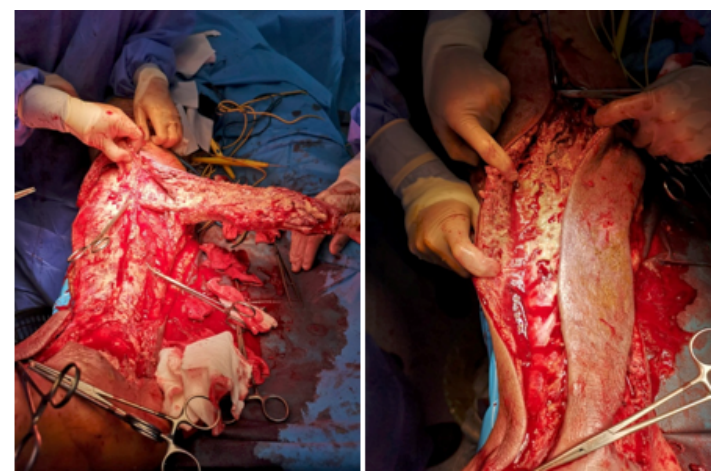

Fig 1. The excision of the necrotic tissues

Post-operatively, the patient was carefully monitored. Supportive therapies, which include preservation of fluid and electrolyte balance, blood product transfusion and nutritional support, were provided as needed. His laboratory parameters subsequently normalized. Negative pressure wound therapy with polyurethane foam was applied all over the right calf. (fig. 2). The foam was changed every 2 days in aseptic conditions for checking the evolution of the wounds. The status of the lesions was advantageous after 7 days under continuous pressure level of $125 \mathrm{mmHg}$. The defect was covered with skin graft after 7 days. It was decided to use vacuum therapy also after the grafting (fig 3). The foam was changed every 5 days. In the first 3 days continous negative pressure was applied and after intermittent subatmospheric pressure $(125 \mathrm{mmHg} /$ $75 \mathrm{mmHg}$ ). The skin grafts were totally integrated after 15 days.

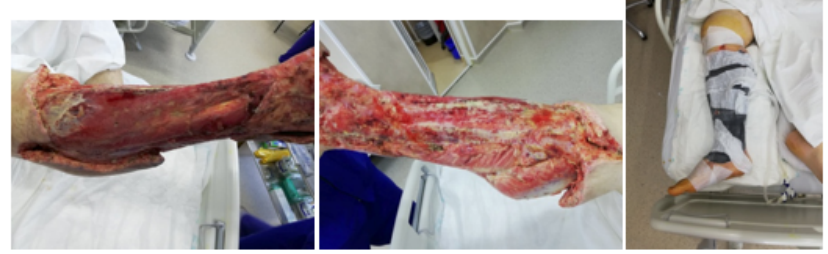

Fig 2. The fourth day post-debridement. Vacuum assisted therapy with polyurethane foam

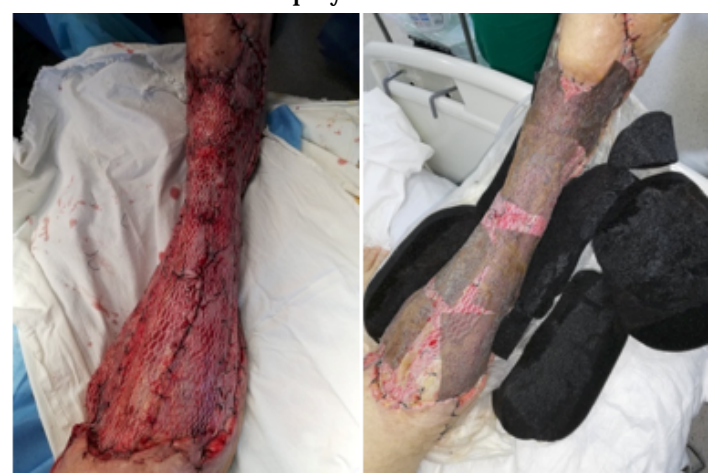

Fig 3. The right lower leg immediately after skin grafting. The fifth day postoperative -the skin grafts cover with silver dressing and polyurethane foam

The evolution was favourable. The patientfullyrecovered after 30 days of hospitalization and left the plastic surgery department in a good clinical condition.

\section{Results and discussions}

Early diagnosis of NF is important. The proper management consists in antibiotic therapy, aggressive surgical treatment and supportive therapy [5]. After surgical debridement negative pressure wound therapy is recommended [4]. For our patient we used negative pressure wound therapy with polyurethane foam after the second intervention, but also 2 weeks after the skin grafting.

Negative pressure wound therapy is used more and more in the last two decades for wound healing. The principal indications for using NPWT are acute and traumatic lesions, dehisced incisions, stasis, diabetic or pressure ulcers, flaps and meshed grafts [7]. In NF application of NPWT is a vital step after the removal of the septic fascia together with the unhealthy tissue [8]. There are different types of foam dressing, but in our case we used the polyurethane foam.

NPWT produces wound healing via four mechanisms: macrodeformation, microdeformation, fluid removal and alteration of the wound environment. The wound shrinkage is called the macrodeformation and appears when suction is applied to the foam [9]. In our case the polyurethane foam was used circumferentially on the right thigh creating compressive forces, part of the macrodeformation mechanism.

Microdeformation is the process that becomes noticeable due to the interaction of the mechanical forces, such as the compression and the tension from the polyurethane foam, with the hydrostatic forces from the extracellular fluid. The forces differ considerably across the wound producing changes in the cytoskeleton and activating the granulation tissue formation $[9,10]$. The fluid removal is essential for permitting the compression forces to influence the microvessels to increase blood flow and perfusion of the tissue [11]. The structure of the foam is like a three-dimensional net allowing a better fluid drainage [9]. We remove $800 \mathrm{~mL}$ per day of fluid in the first 7 days and after that $800 \mathrm{~mL}$ every 2 days. The proper moist sterile wound environment is maintained by the foam [12]. After the skin grafting, to our patients, silver dressing was added beneath the polyurethane foam in order to prevent bacterial contamination.

The chemical process of the formation of the polyurethane foam is described by the reaction of polyols, isocyanates and water [13] and the final characteristics of the polyurethanes rest on the chemical structure of the elements [14]. The water produces bubbles and foam creating an enlarging structure. Due to the open pored structure the pressure is easily spread over the sponge and encourages an effective therapy [13]. The flexibility of the foam permits to adapt it to all the irregular wound edges. Another material with a good flexibility used in plastic surgery for breast reconstruction is the acellular dermal matrix that offers stability of the lower pole [15]. The polyurethane foam is considered also to be an optimal wound dressing being able to control exudates, to block external contamination, to provide a moist environment and to permit a safely removal with no dressing remained in the wounds [16].

\section{Conclusions}

Necrotizing fasciitis is a life-threatening condition and a public health issue. Rapid diagnosis of the disease and surgical debridement are the most important steps in the management of treatment of these patients. Even if there are not sufficient studies regarding the effects of vacuum assisted therapy with polyurethane foam in necrotizing fasciitis it is clear that the treatment should be started after debridement. In our patient the evolution was favourable the polyurethane foam created a proper environment of wound healing. Further research into the negative pressure wound therapy with polyurethane foam in necrotizing fasciitis is needed. 


\section{References}

1.BONNE S, KADRI SS, Infectious disease clinics of North America, 31, No. 3, 2017, p. 497-511.

2.MISIAKOSEP, BAGIASG, PATAPISP, SOTIROPOULOSD, KANAVIDISP, MACHAIRAS A, Frontiers in Surgery, 36, No. 1, 2014.

3. HAKKARAINEN TW, KOPARI NM, PHAM TN, EVANS HL, Current problems in surgery, 51, No. 8, 2014, p. 344-362.

4.ZHAO J C, ZHANG BR, SHI K, ET AL, BMC Infect Dis, 17, No. 1, 2017, p. 792.

5. PUVANENDRAN R, HUEY JCM, PASUPATHY S, Canadian Family Physician, 55, No. 10, 2009, p. 981-987.

6.RAZAFIMANJ ATO NN, RASOAMAMPIANINA LE, RAVOATRARILANDY

M, ET AL, Pan Afr Med J, No. 16, 2013, p. 108.

7. YADAV S, RAWAL G, BAXI M, Pan Afr Med J, No. 28, 2017, p. 246.

8. EL-SABBAGH AH, Chin J Traumatol, 20, No. 2, 2017, p. 103-107.

9.PANAYI AC, LEAVITT T, ORGILL DP, World J Dermatol, 6, No. 1, 2017, p. 1-16.
10. SAXENA V, HWANG CW, HUANG S, EICHBAUM Q, INGBER D, ORGILL DP, Plast Reconstr Surg, 114, No. 5, 2004, p. 1086-1096.

11.ARGENTA LC, MORYKWAS MJ , Ann Plast Surg, 38, No. 6, 1997, p. 563-576.

12. HUANG C, LEAVITT T, BAYER LR, ORGILL DP, Curr Probl Surg, 51, No. 7, 2014, p. 301-331.

13. RADUCU, L, COZMA, C.N., BALCANGIU STROESCU, A.E., AVINO, A., TANASESCU, M.D., BALAN, D.G., JECAN, C.R., Rev. Chim. (Bucharest), 69, no. 3, 2018, p. 585-586.

14.DULDNER, M, BARTHA, E, IANCU, S, CAPITANU, S, NICA ,S, GAREA, S, Mat. Plast., 53, no 3, 2016, p. 347-353.

15.FILIP, C.I., BERBECE, S., RADUCU, L., FLORESCU, I.P., ARDELEANU, V.., JECAN, C.R., Mat.Plast., 54, no. 3, 2017, p. 414-417

16. IMRAN FH, KARIM R, MAAT NH, J Med Case Rep, 10, No. 1, 2016, p. 120.

$\overline{\text { Manuscript received: } 13.09 .2018}$ 